\title{
Dietary Supplements of Two Doses of Calcium Salts of Conjugated Linoleic Acid During the Transition Period and Early Lactation*
}

\author{
E. Castañeda-Gutiérrez, T. R. Overton, W. R. Butler, and D. E. Bauman \\ Department of Animal Science, Cornell University, Ithaca, NY 14853
}

\section{ABSTRACT}

Reduction of milk fat secretion by the use of conjugated linoleic acid (CLA) supplements may alleviate energy demands during early lactation. The objective of the present study was to evaluate lactational performance, net energy balance, and reproductive response of dairy cows supplemented with 2 doses of CLA from 2 wk before predicted calving until 9 wk postpartum. Holstein cows $(\mathrm{n}=48)$ were divided into 3 treatment groups: 1) control, 2) low dose CLA treatment (CLA-1), and 3) high dose CLA treatment (CLA-2). Supplements for all treatments provided $230 \mathrm{~g} / \mathrm{d}$ of fat; the control group received Ca salts of palm fatty acid distillate and the CLA groups received a mixture of Ca salts of CLA isomers and $\mathrm{Ca}$ salts of palm fatty acid distillate (31.6 and $63.2 \mathrm{~g} / \mathrm{d}$ of CLA isomers for CLA-1 and CLA-2, respectively). Supplementation with CLA resulted in an 11 and $21 \%$ decrease in milk fat yield for CLA-1 and CLA-2, respectively. Milk production and secretion of other milk components did not differ among treatments. Milk energy output was significantly reduced with CLA-2, but net energy balance, body weight, and body condition scores were unaffected. Treatment had no effect on hepatic triglyceride concentration or plasma glucose and insulin, but nonesterified fatty acids tended to be lower for CLA-1. There were no consistent doserelated effects on reproduction variables, and no adverse effects were observed during the treatment or posttreatment period. Supplemental CLA was effective in reducing milk fat content, but it did not have a significant effect on milk yield or net energy balance.

(Key words: conjugated linoleic acid, early lactation, milk fat depression, net energy balance)

Abbreviation key: CLA = conjugated linoleic acid, CLA-1 = low dose CLA treatment, CLA-2 = high dose CLA treatment, $\mathbf{E E}=$ ether extract, $\mathbf{M E}=$ metaboliz-

Received June 8, 2004

Accepted November 15, 2004.

Corresponding author: D. E. Bauman; e-mail: deb6@cornell.edu.

*Supported in part by BASF AG (Ludwigshafen, Germany), Bioproducts Inc. (Fairlawn, OH), and Cornell Agricultural Experiment Station. able energy, $\mathbf{M F D}=$ milk fat depression, $\mathbf{M P}=$ metabolizable protein.

\section{INTRODUCTION}

The onset of lactation in the dairy cow is characterized by a dramatic increase in the nutrient demands for milk synthesis that coincides with a prepartum decline in DMI; this leads to negative energy balance in early lactation (Bell, 1995; Grummer, 1995; Goff and Horst, 1997). Extreme negative energy balance predisposes the cow to the occurrence of several periparturient diseases and health problems that can impact milk production and profitability of the cow during the entire lactation (Gröhn et al., 1995; Drackley, 1999). Most approaches to alleviate the period of negative energy balance focus on mitigating the decrease in DMI and include the partial substitution of forages with more energy-dense concentrates and fat supplements (Grummer, 1995). However, high amounts of concentrate may predispose transition cows to excessive decreases in DMI as they approach parturition and potentially increase incidence of displaced abomasum (Coppock et al., 1972; Mashek and Grummer, 2003). In addition, DMI is inversely related to the amount of fat in the diet and is affected by the type of fat and the parity of the animal (Allen, 2000; Hayirli et al., 2002).

An alternative approach to reduce the extent of negative energy balance is to decrease energy output during early lactation through temporary milk fat depression (MFD). Diet-induced MFD represents a situation where milk fat yield decreases without alteration of milk and milk protein yield. According to the biohydrogenation theory of MFD, the presence of unsaturated fatty acids from the diet and an altered rumen environment results in the formation of unique fatty acid intermediates that inhibit milk fat synthesis (Bauman and Griinari, 2003). One of these intermediates is trans-10, cis-12 CLA (Baumgard et al., 2000), and supplementation with rumen-protected CLA to pregnant, lactating cows for 20 wk promoted MFD with no apparent adverse effects (Perfield et al., 2002); therefore, it may constitute an efficient strategy to reduce milk energy output. Bernal-Santos et al. (2003) supplemented rumen-protected CLA to cows during the transition pe- 
riod, but no response was observed on milk fat percentage during the first $2 \mathrm{wk}$ postpartum. Thereafter, CLA induced a reduction in milk fat content, but milk yield simultaneously increased so that there was no overall improvement in energy balance. Additionally, a more rapid return to estrous cycling was observed, but the number of animals was limited.

The objective of the present study was to evaluate the potential of 2 doses of rumen-protected CLA as an approach to reduce milk energy output in transition and early lactation cows, and this included effects on productive and reproductive performance.

\section{MATERIALS AND METHODS}

\section{Animals and Design}

All procedures involving animals were approved by the Cornell University Institutional Animal Care and Use Committee. Multiparous Holstein cows ( $\mathrm{n}=48$ ) from the Cornell University Dairy Teaching and Research facility were blocked by parity and by 305-d mature equivalent milk production in the previous lactation and assigned in a randomized complete blocked design to one of the following 3 dietary treatments: 1 ) control, consisting of $271 \mathrm{~g} / \mathrm{d}$ of Ca salts of palm fatty acid distillate (EnerGII; Bioproducts Inc., Fairlawn, $\mathrm{OH}) ; 2$ ) conjugated linoleic acid dose 1 (CLA-1), consisting of $147 \mathrm{~g} / \mathrm{d}$ of Ca salts of mixed isomers of CLA (Bioproducts Inc.) and $136 \mathrm{~g} / \mathrm{d}$ of Ca salts of palm fatty acid distillate; or 3 ) conjugated linoleic acid dose 2 (CLA-2) consisting of $295 \mathrm{~g} / \mathrm{d}$ of Ca salts of mixed isomers of CLA.

Supplements of Ca salts of palm fatty acid distillate and Ca salts of CLA contained 85 and $78 \%$ fat, respectively. The 3 supplements provided the same intake of fat $(230 \mathrm{~g} / \mathrm{d})$ and were top-dressed once daily on the TMR from $21 \mathrm{~d}$ before expected day of calving to 63 DIM. The CLA- 1 and CLA-2 treatments provided 31.6 and $63.2 \mathrm{~g} / \mathrm{d}$ of CLA isomers, respectively. The 4 predominant CLA isomers in the supplements were trans8, cis-10 (21.2\%), cis-9, trans-11 (21.8\%), trans-10, cis12 (29.0\%), and cis-11, trans-13 (28.0\%). The predominant fatty acids in the Ca salts of palm fatty acid distillate were palmitic $(42.6 \%)$, oleic $(40.6 \%)$, and linoleic acids $(10.1 \%)$.

Cows were fed TMR formulated using the Cornell Net Carbohydrate and Protein System (Fox et al., 2004). The diets for the prepartum period and the postpartum period are described in Table 1, and all treatment groups received the same diet during these specific periods. The TMR samples were taken weekly, DM content was determined by drying at $54^{\circ} \mathrm{C}$ until a constant weight was reached, and then samples were composited at 4 -wk intervals. Feed composites were ana-
Table 1. Ingredient and chemical composition of the prepartum and postpartum diets. ${ }^{1}$

\begin{tabular}{lcc}
\hline Variable & Prepartum & Postpartum \\
\hline Ingredient, \% of DM & & \\
Corn silage & 29.88 & 31.08 \\
Legume silage & 14.90 & 16.32 \\
Alfalfa hay & 17.18 & 6.92 \\
High moisture corn & 19.61 & 15.54 \\
Citrus pellets & - & 7.77 \\
Soybean meal & 4.71 & 5.24 \\
Expeller soybean meal & 4.71 & 8.35 \\
Cotton seed & 5.88 & 5.36 \\
Yeast & 0.86 & \\
Limestone & - & 1.09 \\
Sodium bicarbonate & - & 1.07 \\
Salt & 0.31 & - \\
Mineral mix & \\
Chemical analysis, \% of DM & 1.96 & 1.26 \\
CP & & \\
ADF & 16.37 & 17.75 \\
NDF & 23.30 & 20.45 \\
NFC & 34.60 & 32.53 \\
EE & 36.90 & 37.65 \\
Ash & 4.20 & 4.20 \\
Ca & 7.07 & 7.85 \\
P & 0.95 & 1.21 \\
Mg & 0.40 & 0.36 \\
K & 0.29 & 0.31 \\
NE, Mcal/kg & 1.51 & 1.40 \\
\hline & & 1.61 \\
\hline Val & 1.63 &
\end{tabular}

${ }^{1}$ Values represent averages of samples composited every $4 \mathrm{wk}$ and do not include the top-dress supplement.

${ }^{2}$ Diamond-V Mills, Inc. (Cedar Rapids, IA).

${ }^{3}$ The mix (DM basis) contained $20 \% \mathrm{Cl}, 13 \% \mathrm{Na}, 10 \% \mathrm{Ca}, 8.0 \% \mathrm{Mg}$, $8.0 \% \mathrm{~S}, 1.0 \% \mathrm{~K}, 57 \mathrm{ppm}$ of $\mathrm{Co}, 800 \mathrm{ppm}$ of $\mathrm{Cu}, 2000 \mathrm{ppm}$ of $\mathrm{Fe}, 90$ $\mathrm{ppm}$ of I, $5400 \mathrm{ppm}$ of Mn, $6200 \mathrm{ppm}$ of Zn, $20 \mathrm{ppm}$ of Se, $550 \mathrm{IU} / \mathrm{g}$ of vitamin A, $132 \mathrm{IU} / \mathrm{g}$ of vitamin D, and $2.97 \mathrm{IU} / \mathrm{g}$ of vitamin $\mathrm{E}$.

${ }^{4} \mathrm{NFC}$ (nonfibrous carbohydrate $)=100-(\mathrm{NDF}-$ neutral detergent insoluble $\mathrm{CP}+\mathrm{CP}+$ ash + ether extract).

lyzed by wet chemistry methods for $\mathrm{CP}, \mathrm{ADF}$, NDF, ether extract (EE), and minerals (Dairy One Cooperative Inc., Ithaca, NY), and values are reported in Table 1.

Cows were housed in tie stalls and fed at ad libitum intake to allow about $10 \%$ orts. Individual feed intake was recorded from $14 \mathrm{~d}$ before the expected date of calving to 63 DIM. During the post-treatment period (64 to $126 \mathrm{DIM}$ ), cows were combined in groups independent of treatment and fed a common diet. Water and mineral blocks were available throughout the study. Body weight and BCS (5-point system; Wildman et al., 1982) were recorded weekly after the morning milking. After calving, cows were milked $3 \times / \mathrm{d}$, and milk weight was recorded. A milk sample from each milking was taken $1 \mathrm{~d} / \mathrm{wk}$, and a composite was formed based on proportion of daily yield. Composite milk samples were stored at $4^{\circ} \mathrm{C}$ with a preservative (bronopol tablet; D\& F Control System, San Ramon, CA) until analyzed for fat, true protein, and lactose (Dairy One Cooperative 
Table 2. Least squares means for performance and milk composition during the treatment period.

\begin{tabular}{|c|c|c|c|c|c|c|}
\hline \multirow[b]{2}{*}{ Variable } & \multicolumn{3}{|c|}{ Treatment $^{1}$} & \multirow[b]{2}{*}{ SEM } & \multirow[b]{2}{*}{$P$} & \multirow{2}{*}{$\begin{array}{l}\text { Treatment } \\
\times \text { week } \\
(P)\end{array}$} \\
\hline & Control & CLA-1 & CLA-2 & & & \\
\hline \multicolumn{7}{|l|}{ Prepartum performance $^{2}$} \\
\hline $\mathrm{BW}, \mathrm{kg}$ & 722 & 694 & 701 & 15 & 0.38 & 0.43 \\
\hline $\mathrm{BCS}^{3}$ & 3.3 & 3.4 & 3.2 & 0.1 & 0.70 & 0.44 \\
\hline DMI, kg/d & $13.5^{\mathrm{ab}}$ & $14.8^{\mathrm{a}}$ & $12.7^{\mathrm{b}}$ & 0.6 & 0.05 & 0.17 \\
\hline \multicolumn{7}{|l|}{ Postpartum performance ${ }^{4}$} \\
\hline Milk yield, kg/d & 43.4 & 43.8 & 43.8 & 1.5 & 0.98 & 0.70 \\
\hline $\mathrm{BW},{ }^{5} \mathrm{~kg}$ & 611 & 609 & 587 & 15 & 0.46 & 0.96 \\
\hline BCS & 2.6 & 2.7 & 2.5 & 0.1 & 0.38 & 0.77 \\
\hline DMI, kg/d & 21.7 & 21.3 & 20.5 & 0.6 & 0.35 & 0.51 \\
\hline \multicolumn{7}{|l|}{ Milk composition } \\
\hline \multicolumn{7}{|l|}{ Milk fat } \\
\hline Content, \% & $3.82^{\mathrm{a}}$ & $3.43^{\mathrm{b}}$ & $3.08^{\mathrm{c}}$ & 0.08 & $<0.001$ & 0.008 \\
\hline Yield, kg/d & $1.65^{\mathrm{a}}$ & $1.46^{\mathrm{b}}$ & $1.30^{\mathrm{c}}$ & 0.05 & $<0.001$ & 0.01 \\
\hline \multicolumn{7}{|l|}{ Milk true protein } \\
\hline Content, \% & 2.85 & 2.81 & 2.79 & 0.04 & 0.65 & 0.73 \\
\hline Yield, kg/d & 1.24 & 1.22 & 1.20 & 0.04 & 0.76 & 0.10 \\
\hline \multicolumn{7}{|l|}{ Milk lactose } \\
\hline Content, \% & 4.74 & 4.77 & 4.70 & 0.05 & 0.60 & $<0.001$ \\
\hline Yield, kg/d & 2.06 & 2.09 & 2.05 & 0.05 & 0.93 & 0.81 \\
\hline \multicolumn{7}{|l|}{ Energy partitioning } \\
\hline Milk energy output, ${ }^{6} \mathrm{Mcal} / \mathrm{d}$ & $30.17^{\mathrm{a}}$ & $28.52^{\mathrm{ab}}$ & $26.76^{\mathrm{b}}$ & 0.97 & 0.03 & 0.51 \\
\hline Net energy balance, ${ }^{7} \mathrm{Mcal} / \mathrm{d}$ & -3.34 & -2.45 & -1.74 & 0.73 & 0.54 & 0.26 \\
\hline
\end{tabular}

a,b,c Means within a row with different superscripts differ.

${ }^{1}$ Cows received a dietary fat supplement consisting of $271 \mathrm{~g} / \mathrm{d}$ of Ca salts of palm fatty acid distillate (control), Ca salts of a mixture of conjugated linoleic acid (CLA) isomers (147g/d containing $32 \mathrm{~g} / \mathrm{d}$ of CLA isomers; $9 \mathrm{~g} / \mathrm{d}$ of CLA trans-10, cis-12) plus $136 \mathrm{~g} / \mathrm{d}$ of palm fatty acid distillate (CLA-1), or Ca salts of a mixture of CLA isomers ( $295 \mathrm{~g} / \mathrm{d}$ containing $63 \mathrm{~g} / \mathrm{d}$ of CLA isomers; $18 \mathrm{~g} / \mathrm{d}$ of CLA trans-10, cis-12; CLA-2).

${ }^{2}$ Values represent data obtained from 2 wk prepartum to parturition.

${ }^{3}$ Cows were scored weekly by the same individual using a 5 -point scale.

${ }^{4}$ Values represent data obtained from parturition to 9 wk postpartum.

${ }^{5}$ Cows were weighed after milking on $1 \mathrm{~d} / \mathrm{wk}$.

${ }^{6}$ Calculated based on NRC $(2001)$ as follows: [ $(0.0929 \times$ milk fat percentage $)+(0.0547 \times$ milk true protein percentage $)+(0.0395 \times$ milk lactose percentage $)] \times$ milk yield.

${ }^{7}$ Calculated based on NRC (2001) where NE balance equals: [( $\mathrm{DMI} \times \mathrm{NE}_{\mathrm{L}}$ in the diet and the supplement) $\left.-\left(\mathrm{BW}^{0.75} \times 0.08\right)\right)+$ milk energy].

Inc.) with the analytical and calibration methods described by Bernal-Santos et al. (2003). Additional aliquots of milk were taken, and a composite was formed during wk 1 to 6 postpartum. This composite was immediately frozen and stored at $-20^{\circ} \mathrm{C}$ until analyzed for fatty acids.

Blood samples were taken at 10 and $5 \mathrm{~d}$ prepartum, $3 \times /$ wk during the first $11 \mathrm{wk}$ of lactation, and once weekly from wk 12 to 18 postpartum. Blood (10 mL) was obtained via coccygeal venipuncture and was collected in vacuum tubes (Becton Dickinson Vacutainer Systems, Franklin Lakes, NJ) containing sodium heparin $(100 \mathrm{U} / \mathrm{mL}$ of blood). Plasma was harvested within 20 min after collection by centrifugation $(2800 \times g$ for $15 \mathrm{~min}$ at $4^{\circ} \mathrm{C}$ ) and stored at $-20^{\circ} \mathrm{C}$ until metabolite and hormone analysis.

Liver samples were obtained via percutaneous trochar biopsy (Veenhuizen et al., 1991) on d $2 \pm 1$ and on d $21 \pm 1$ postpartum (mean \pm SD). Liver samples were immediately frozen in liquid nitrogen and stored at $-80^{\circ} \mathrm{C}$ until analyzed for triglyceride content.

Estrus was synchronized with an intramuscular injection of $100 \mathrm{mg}$ of GnRH analogue (Cystorelin; Abbott Laboratories, North Chicago, IL) at d $70 \pm 3$ (mean \pm SD) postpartum; $7 \mathrm{~d}$ later, cows received an injection of $30 \mathrm{mg}$ of $\mathrm{PGF}_{2 \alpha}$ analogue (Lutalyse; Pharmacia \& Upjohn, Kalamazoo, MI); $48 \mathrm{~h}$ later, they received an injection of $100 \mathrm{mg}$ of $\mathrm{GnRH}$ and were inseminated 4 to $8 \mathrm{~h}$ later. Pregnancy was diagnosed by rectal palpation at $42 \mathrm{~d}$ after insemination. After the experimental period (>126 DIM), nonpregnant cows were resynchronized or inseminated when estrus was visually detected; if conception occurred before $185 \mathrm{~d}$ postpartum, this was recorded and used for statistical analysis.

A total of 46 of the 48 cows completed the treatment period. One cow from each CLA treatment group was excluded (all analysis) because of health reasons (chronic laminitis). In addition, 2 cows in the CLA-1 

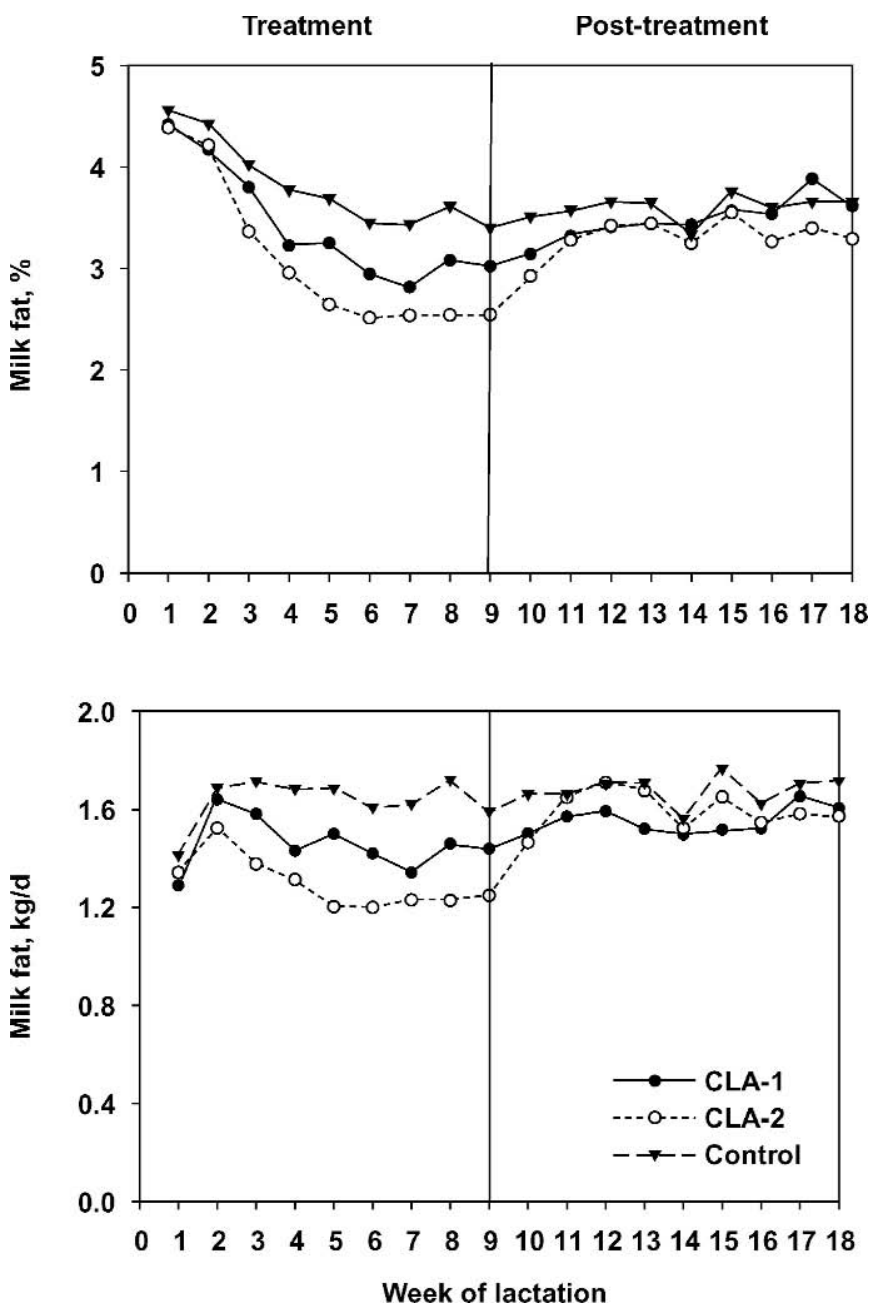

Figure 1. Temporal pattern of milk fat percentage and milk fat yield during the treatment $(n=46)$ and post-treatment periods $(n=$ 44). Cows received a dietary fat supplement for the first 9 wk of lactation consisting of Ca salts of $271 \mathrm{~g} / \mathrm{d}$ of palm fatty acid distillate (control), Ca salts of a mixture of conjugated linoleic acid (CLA) isomers $(147 \mathrm{~g} / \mathrm{d}$ containing $32 \mathrm{~g} / \mathrm{d}$ of CLA isomers; $9 \mathrm{~g} / \mathrm{d}$ of CLA trans10 , cis-12) plus $136 \mathrm{~g} / \mathrm{d}$ of palm fatty acid distillate (CLA-1), or Ca salts of a mixture of CLA isomers ( $295 \mathrm{~g} / \mathrm{d}$ containing $63 \mathrm{~g} / \mathrm{d}$ of CLA isomers; $18 \mathrm{~g} / \mathrm{d}$ of CLA trans-10, cis-12; CLA-2). Values are least squares means for each treatment group, and SEM averaged $0.08 \%$ and $0.05 \mathrm{~kg} / \mathrm{d} ; P$-value for treatment $\times$ week interaction during treatment is 0.01 .

treatment group completed the treatment period but not the post-treatment period because of chronic laminitis and death caused by a respiratory problem.

\section{Fatty Acid Analysis}

The extraction and preparation of methyl esters of milk fatty acids was performed as described by BernalSantos et al. (2003). The fatty acid methyl esters were quantified using a gas chromatograph (Hewlett Packard HP6890; Wilmington, DE) equipped with a CP-Sil
88 capillary column $(100 \mathrm{~m} \times 0.25 \mathrm{~mm}$ i.d. with $0.2-\mu \mathrm{m}$ film thickness; Varian Instruments, Walnut Creek, CA) under conditions as previously described by Perfield et al. (2002).

Lack of response in milk fat has been observed when Ca salts of CLA were fed several months after supplement manufacture (D. E. Bauman, unpublished data), and the cause appeared to be a polymerization of fatty acids that decreased the bioavailability and analytical detection of the CLA isomers (Asgeir Sæbø, Natural ASA, Hovdebydga, Norway; personal communication, 2002). In the present study, the fatty acid profile of the dietary supplements was analyzed monthly, and we observed a consistent CLA composition throughout the experiment. The analysis of the supplements was as described by Bernal-Santos et al. (2003) with gas chromatography procedures as described for milk fat.

Fatty acid peaks were identified using pure methyl ester standards (NuChek Prep, Elysian, MN). A butter oil reference standard (CRM 164; Commission of the European Community Bureau of References, Brussels, Belgium) was used to determine recovery factors for individual fatty acids and as a routine quality control.

\section{Metabolite and Hormone Analysis}

One plasma sample chosen from the end of each week was analyzed for NEFA and glucose. Plasma NEFA were quantified by enzymatic analysis (NEFA-C kit; Wako Chemicals, Richmond, VA) as previously described (Sechen et al., 1990). Glucose was determined by enzymatic analysis (procedure no. 510-A; Sigma Diagnostics, St. Louis, MO).

Plasma concentrations of progesterone and estradiol were determined by radioimmunoassay (Elrod and Butler, 1993; Beam and Butler, 1997). Progesterone was analyzed on the plasma samples obtained $3 \times /$ wk during the first 11 wk of lactation, whereas estradiol was analyzed on the plasma samples from the first $3 \mathrm{wk}$ postpartum. Ovulation was determined based on temporal pattern and concentration of plasma progesterone according to the criteria described by Butler et al. (1981). Insulin was quantified by radioimmunoassay (McGuire et al., 1995) at wk 3, 6, and 9 postpartum using a composite sample formed from the 3 weekly plasma samples. Bovine insulin was used for iodination and standards (lot 615-70N-80; Lilly Research Laboratories, Greenfield, IN).

For triglyceride analysis, liver tissue was homogenized with a mixture of (2:1) chloroform:methanol, and lipid was extracted (Folch et al., 1957). Analysis of the extract involved a colorimetric method (Fletcher, 1968) with modifications described by Foster and Dunn (1973). 
Table 3. Fatty acid composition of milk fat from cows during wk 6 of treatment.

\begin{tabular}{|c|c|c|c|c|c|}
\hline \multirow[b]{2}{*}{ Fatty acid, \% } & \multicolumn{3}{|c|}{ Treatment $^{1}$} & \multirow[b]{2}{*}{ SEM } & \multirow[b]{2}{*}{$P$} \\
\hline & Control & CLA-1 & CLA-2 & & \\
\hline $4: 0$ & 4.97 & 4.99 & 4.82 & 0.20 & 0.80 \\
\hline $6: 0$ & $2.18^{\mathrm{a}}$ & $1.94^{\mathrm{ab}}$ & $1.85^{\mathrm{b}}$ & 0.08 & 0.01 \\
\hline 8:0 & $1.10^{\mathrm{a}}$ & $0.91^{\mathrm{b}}$ & $0.86^{\mathrm{b}}$ & 0.05 & 0.004 \\
\hline $10: 0$ & $2.12^{\mathrm{a}}$ & $1.75^{\mathrm{ab}}$ & $1.70^{\mathrm{b}}$ & 0.12 & 0.03 \\
\hline $12: 0$ & 2.22 & 1.91 & 1.90 & 0.12 & 0.12 \\
\hline $14: 0$ & 7.86 & 7.41 & 7.38 & 0.34 & 0.53 \\
\hline $14: 1$ & 0.47 & 0.42 & 0.41 & 0.04 & 0.55 \\
\hline $15: 0$ & 0.56 & 0.64 & 0.64 & 0.03 & 0.15 \\
\hline $16: 0$ & $26.91^{\mathrm{a}}$ & $25.68^{\mathrm{b}}$ & $24.89^{b}$ & 0.37 & 0.001 \\
\hline $16: 1$ & 1.17 & 1.15 & 1.05 & 0.06 & 0.31 \\
\hline $17: 0$ & $0.45^{\mathrm{b}}$ & $0.49^{\mathrm{a}}$ & $0.50^{\mathrm{a}}$ & 0.01 & 0.003 \\
\hline $18: 0$ & 13.52 & 14.19 & 13.93 & 0.50 & 0.64 \\
\hline 18:1 trans -4 & $0.04^{\mathrm{a}}$ & $0.04^{\mathrm{ab}}$ & $0.03^{\mathrm{b}}$ & 0.004 & 0.05 \\
\hline $18: 1$ trans -5 & $0.03^{\mathrm{a}}$ & $0.02^{\mathrm{b}}$ & $0.01^{b}$ & 0.004 & 0.009 \\
\hline $18: 1$ trans $-6-8$ & $0.43^{\mathrm{b}}$ & $0.48^{\mathrm{ab}}$ & $0.56^{\mathrm{a}}$ & 0.04 & 0.003 \\
\hline $18: 1$ trans -9 & $0.38^{\mathrm{b}}$ & $0.41^{\mathrm{a}}$ & $0.49^{\mathrm{a}}$ & 0.02 & 0.001 \\
\hline $18: 1$ trans -10 & 0.63 & 0.81 & 1.45 & 0.30 & 0.13 \\
\hline $18: 1$ trans -11 & $1.53^{\mathrm{b}}$ & $1.73^{\mathrm{ab}}$ & $2.07^{\mathrm{a}}$ & 0.14 & 0.002 \\
\hline $18: 1$ trans -12 & $0.74^{\mathrm{b}}$ & $0.82^{\mathrm{b}}$ & $0.94^{\mathrm{a}}$ & 0.04 & $<0.001$ \\
\hline $18: 1$ cis-9 & 25.45 & 26.39 & 25.70 & 0.75 & 0.65 \\
\hline $18: 2$ cis -9, cis -12 & $3.80^{\mathrm{b}}$ & $4.01^{\mathrm{ab}}$ & $4.25^{\mathrm{a}}$ & 0.13 & 0.05 \\
\hline $18: 2$ cis -9, trans -11 & $0.04^{\mathrm{b}}$ & $0.52^{\mathrm{ab}}$ & $0.61^{\mathrm{a}}$ & 0.03 & 0.005 \\
\hline $18: 2$ trans -10, cis -12 & $<0.01^{\mathrm{c}}$ & $0.02^{\mathrm{b}}$ & $0.04^{\mathrm{a}}$ & 0.003 & $<0.001$ \\
\hline $18: 3$ & 0.38 & 0.42 & 0.58 & 0.07 & 0.13 \\
\hline $20: 0$ & 0.09 & 0.10 & 0.09 & 0.003 & 0.17 \\
\hline Others & $2.54^{\mathrm{b}}$ & $2.76^{\mathrm{ab}}$ & $2.99^{\mathrm{a}}$ & 0.07 & $<0.001$ \\
\hline \multicolumn{6}{|l|}{ Summation } \\
\hline$<16$ carbons & 21.47 & 19.96 & 19.56 & 0.76 & 0.18 \\
\hline 16 carbons & $28.08^{\mathrm{a}}$ & $26.83^{\mathrm{ab}}$ & $25.95^{\mathrm{b}}$ & 0.38 & $<0.001$ \\
\hline$>16$ carbons & $47.91^{\mathrm{a}}$ & $50.45^{\mathrm{ab}}$ & $51.50^{\mathrm{b}}$ & 0.97 & 0.03 \\
\hline \multicolumn{6}{|l|}{ Desaturase index ${ }^{2}$} \\
\hline cis-9 $14: 1$ & 0.06 & 0.05 & 0.05 & 0.003 & 0.65 \\
\hline cis-9 16:1 & 0.04 & 0.04 & 0.04 & 0.002 & 0.77 \\
\hline cis-9 18:1 & 0.65 & 0.65 & 0.65 & 0.01 & 0.99 \\
\hline CLA & 0.23 & 0.23 & 0.23 & 0.01 & 0.83 \\
\hline
\end{tabular}

a,b,c Means with a row with different superscripts differ.

${ }^{1}$ Cows received a dietary fat supplement consisting of $271 \mathrm{~g} / \mathrm{d}$ of Ca salts of palm fatty acid distillate (control), Ca salts of a mixture of conjugated linoleic acid (CLA) isomers (147g/d containing $32 \mathrm{~g} / \mathrm{d}$ of CLA isomers; $9 \mathrm{~g} / \mathrm{d}$ of CLA trans-10, cis-12) plus $136 \mathrm{~g} / \mathrm{d}$ of palm fatty acid distillate (CLA-1), or Ca salts of a mixture of CLA isomers (295 g/d containing $63 \mathrm{~g} / \mathrm{d}$ of CLA isomers; $18 \mathrm{~g} / \mathrm{d}$ of CLA trans-10, cis-12; CLA-2).

${ }^{2}$ Defined as [product of $\Delta^{9}$-desaturase] $\div$ [product of $\Delta^{9}$-desaturase + substrate of $\Delta^{9}$-desaturase].

\section{Statistical Analyses}

Individual milk production and DMI values were reduced to weekly means before analysis, and the yields of fat, protein, and lactose were calculated using the weekly mean for milk production.

For all analysis, significance was declared at $P<0.05$, and normality of residuals was verified for all ANOVA. Production variables, metabolites, and fatty acids were evaluated by ANOVA using the PROC MIXED procedure of SAS (2001) for repeated measures. The model included treatment, week of treatment, and cow within treatment as a random variable. When the interaction between treatment and week of treatment was significant $(P<0.05)$, this was also included. Blocking variables (lactation number and 305-d mature equivalent milk production in the previous lactation) were not sig- nificant, and, therefore, they were dropped from the model. Liver triglycerides were evaluated with PROC GLM of SAS, and the value from the first biopsy (d 2 \pm 1 ) was used as a covariate for the second biopsy (d $21 \pm 1)$.

Number of ovulations before synchronization and services per conception were analyzed using PROC GLM procedure of SAS (2001). Percentage of cows pregnant before 126 and 185 DIM, proportion of cows with estrogen-active follicles, and proportion of cows with ovulation in the first $21 \mathrm{~d}$ were analyzed with a $\chi^{2}$ test using PROC MIXED procedure of SAS (2001), where cow and treatment were class variables, and treatment was included in the model. For all analyses described previously, least squares means were calculated, and differences between treatments were detected with the Tukey's adjustment. 

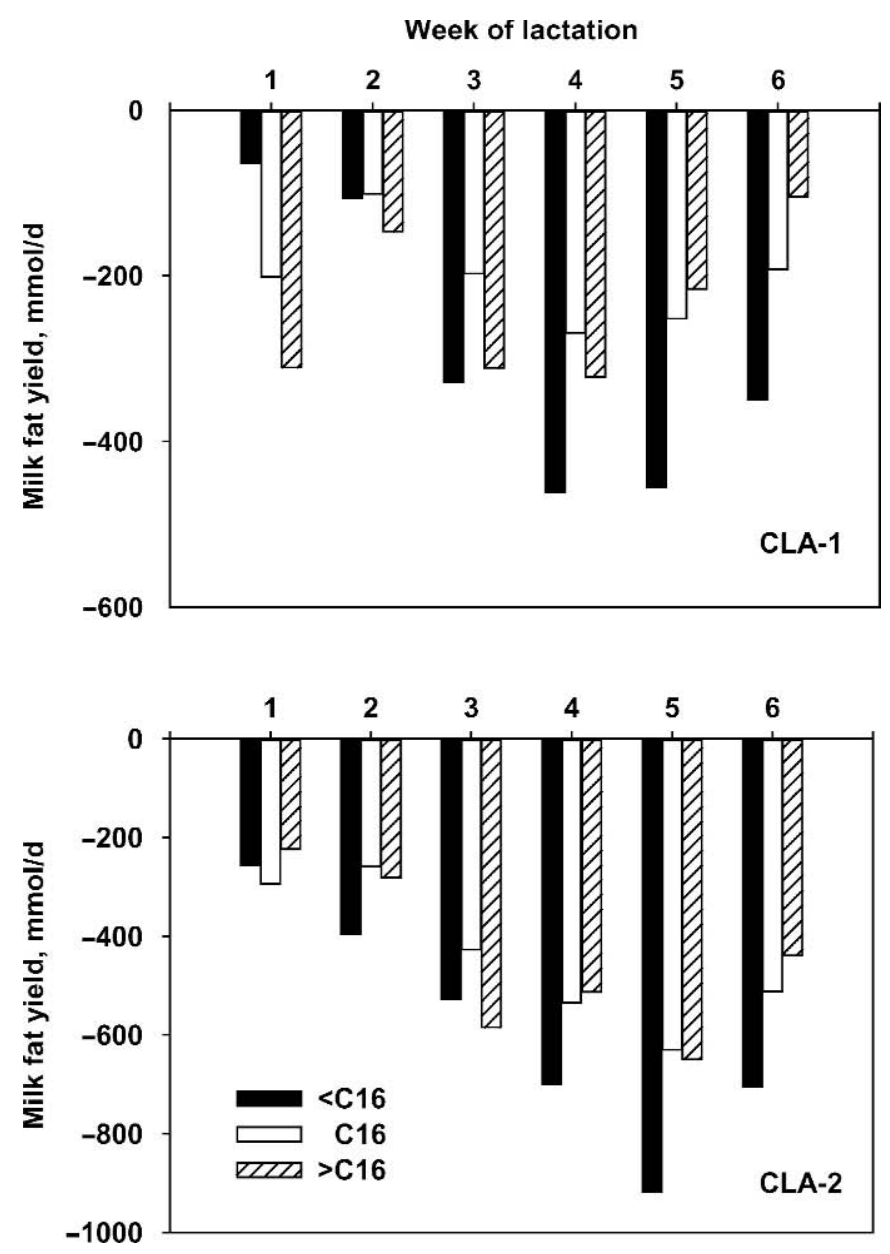

Figure 2. Temporal pattern of reduction in the secretion of milk fatty acids classified by their origin for cows supplemented with CLA1 [top panel; Ca salts of a mixture of conjugated linoleic acid (CLA) isomers $(147 \mathrm{~g} / \mathrm{d}$ containing $32 \mathrm{~g} / \mathrm{d}$ of CLA isomers; $9 \mathrm{~g} / \mathrm{d}$ of CLA trans$10, c i s-12$ ) plus $136 \mathrm{~g} / \mathrm{d}$ of palm fatty acid distillate] and CLA-2 [bottom panel; Ca salts of a mixture of CLA isomers ( $295 \mathrm{~g} / \mathrm{d}$ containing 63 $\mathrm{g} / \mathrm{d}$ of CLA isomers; $18 \mathrm{~g} / \mathrm{d}$ of CLA trans-10, cis -12)]. Values represent differences in least squares means compared to control; $P$-values of treatment $\times$ week interaction were $0.02,0.02$, and 0.41 for fatty acids $<\mathrm{C} 16, \mathrm{C} 16$, and $>\mathrm{C} 16$, respectively.

Days to first ovulation and days to pregnancy were compared by survival analysis using PROC LIFETEST procedure of SAS (2001). Cows that did not ovulate before synchronization were censored (one cow from each treatment), as well as cows that did not become pregnant before 185 DIM (3 cows from CLA-1, 5 cows from CLA-2, and 8 cows from control group).

\section{RESULTS AND DISCUSSION}

Supplementation with both doses of CLA induced a progressive reduction in milk fat, and the decrease was significant by the third week of lactation $(P<0.05$; Figure 1). Relative to the control group, CLA supple- ments caused an average depression of 11 and $21 \%$ in milk fat yield over the 9 -wk treatment period for CLA1 and CLA-2, respectively (Table 2). The effect of CLA on milk fat was reversible, and treated groups returned to levels similar to the control when supplements were terminated (Figure 1). The reduction caused by CLA-1 was similar to that reported in the early lactation study by Bernal-Santos et al. (2003), where the Ca salts of CLA provided a similar dose of the trans-10, cis-12 CLA isomer. However, it is about one-half the magnitude of response reported by Perfield et al. (2002) for cows in established lactation; they observed a $23 \%$ reduction in milk fat yield over a 20 -wk period when $8.8 \mathrm{~g} / \mathrm{d}$ of trans10, cis-12 were supplied as Ca salts.

During early lactation, milk fat response to CLA appeared to be gradual, and nadir was not reached until several weeks postpartum (Bernal-Santos et al., 2003; Selberg et al., 2004; present study, Figure 1). In contrast, abomasal infusion of CLA resulted in an immediate decrease of milk fat during established lactation (Baumgard et al., 2000; Peterson et al., 2002), and supplementation with Ca salts of CLA caused MFD that reached nadir during the first week of treatment (Perfield et al., 2002).

The trans-10, cis-12 CLA isomer was transferred to milk fat of CLA-supplemented cows at the first week postpartum in the present study (data not shown) and in previous work (Bernal-Santos et al., 2003). Therefore, the diminished response during the first weeks postpartum cannot be attributed to a limitation in mammary uptake of this CLA isomer. The cause is unknown, but may be due to a decrease in sensitivity or responsiveness of cows during early lactation, where many key enzymes and biochemical pathways are altered to support the onset of lactation (Bauman, 2000). Consistent with this, Moore et al. (2004) demonstrated a reduction in milk fat immediately postpartum when larger doses of trans-10, cis-12 CLA were used. They supplemented Ca salts of CLA at doses ranging from 12 to $37 \mathrm{~g} / \mathrm{d}$ of trans-10, cis-12 CLA and observed a significant dose-dependent decrease in milk fat at 2 wk postpartum.

Experiments supplementing CLA in early lactation cows have often reported an increase in milk yield (Giesy et al., 1999; Bernal-Santos et al., 2003) and milk protein yield (Medeiros et al., 2000); however, this is not always observed. Milk yield, milk protein, and lactose were not affected by treatment in the present study (Table 2) or in other investigations during early lactation (Moore et al., 2004; Selberg et al., 2004). Results are consistent during established lactation where no increase in milk production or milk protein yield has been observed with CLA supplementation to cows fed TMR diets (Chouinard et al., 1999a,b; Baumgard et 
Table 4. Least squares means of plasma and liver concentrations of insulin and metabolites during the treatment period.

\begin{tabular}{lccccc}
\hline & \multicolumn{3}{c}{ Treatment $^{1}$} \\
\cline { 2 - 4 } Plasma variable & Control & CLA-1 & CLA-2 & SEM & $P$ \\
\hline Insulin, ${ }^{2} \mathrm{ng} / \mathrm{mL}$ & & & & & \\
wk 3 & 0.20 & 0.19 & 0.19 & 0.03 & 0.98 \\
wk 6 & 0.29 & 0.30 & 0.29 & 0.03 & 0.17 \\
wk 9 & 0.33 & 0.31 & 0.29 & 0.04 & 0.87 \\
Glucose, ${ }^{3} \mathrm{mg} / \mathrm{dL}$ & 53.5 & 53.6 & 54.4 & 1.0 & 0.78 \\
NEFA, ${ }^{\mu} \mu \mathrm{M}$ & 393 & 305 & 349 & 29 & 0.10 \\
Liver triglycerides, \% of wet weight & 3.7 & 3.6 & & & \\
d 2 & 6.8 & 5.0 & 7.4 & 1.0 & 0.79 \\
d 21 & & & & 0.46 \\
\hline
\end{tabular}

${ }^{1}$ Cows received a dietary fat supplement consisting of $271 \mathrm{~g} / \mathrm{d}$ of Ca salts of palm fatty acid distillate (control), Ca salts of a mixture of conjugated linoleic acid (CLA) isomers (147g/d containing $32 \mathrm{~g} / \mathrm{d}$ of CLA isomers; $9 \mathrm{~g} / \mathrm{d}$ of CLA trans-10, cis-12) plus $136 \mathrm{~g} / \mathrm{d}$ of palm fatty acid distillate (CLA-1), or Ca salts of a mixture of CLA isomers (295 g/d containing $63 \mathrm{~g} / \mathrm{d}$ of CLA isomers; $18 \mathrm{~g} / \mathrm{d}$ of CLA trans-10, cis-12; CLA-2).

${ }^{2}$ The 3 weekly plasma samples were composited for each cow, and values are averages for week as indicated.

${ }^{3}$ Average of a single sample taken at the end of each week from -2 to 9 wk postpartum.

${ }^{4}$ Liver biopsies were obtained on $\mathrm{d} 2 \pm 1$ and $21 \pm 1$ (mean \pm SD) postpartum and analyzed for triglyceride content. Values of d 2 were used as a covariate for $\mathrm{d} 21$.

al., 2001; Perfield et al., 2002). A week $\times$ treatment interaction was observed in lactose percentage because of a lower value in the control group during the first week. This value might have been influenced by the presence of colostrum in one or more samples.

Energy, glucose, and amino acids can be limiting in early lactation (Oldham, 1984; Bell, 1995), and the difference in milk response between early lactation studies may be due to variation in nutrient availability. Based on this, the milk yield response in the early lactation studies has been attributed to the greater availability of energy caused by reduction of milk energy output in a physiological state where synthesis activity in the mammary gland is up-regulated (Bernal-Santos et al., 2003). The metabolizable energy (ME) and metabolizable protein (MP) balances over the first $9 \mathrm{wk}$ postpartum in the study by Bernal-Santos et al. (2003) and the present study were determined using the Cornell Net Carbohydrate and Protein System (Fox et al., 2004). The diet in the present study provided a greater percentage of ME and MP requirements (92 vs. $86 \%$ and 96 vs. $88 \%$ for $\mathrm{ME}$ and $\mathrm{MP}$, respectively). Compared with the study by Bernal-Santos et al. (2003), plasma NEFA concentrations for the control group during the first 8 wk postpartum were also lower during the same period (436 vs. $603 \mu M$, respectively), consistent with the less extensive negative energy balance. Thus, nutrient status may influence whether the CLA-induced reduction in milk fat secretion results in a corresponding increase in milk yield.

Dietary supplements of CLA resulted in changes in the fatty acid composition of milk fat as shown for wk 6 postpartum (Table 3). Fatty acids can be grouped according to their origin: fatty acids synthesized de novo $(<\mathrm{C} 16)$, fatty acids from the uptake of preformed fatty acids $(>\mathrm{C} 16)$, and fatty acids from both sources (C16; McGuire and Bauman, 2002). The CLA-2 treatment slightly increased the proportion of preformed fatty acids and decreased the proportion of C16 in the milk. Fatty acids representing the product and substrate for $\Delta^{9}$-desaturase were used to calculate the desaturase index, and there were no differences among treatments (Table 3). The small shifts in fatty acid composition and the lack of an effect on the desaturase index are comparable with the responses observed with abomasal infusion of low doses of CLA trans-10, cis-12 $(<5 \mathrm{~g} / \mathrm{d}$; Baumgard et al., 2001; Peterson et al., 2002). This suggests that substantial metabolism of the Ca salts of CLA must have occurred in the rumen, so that the "effective dose" was much lower than the amount of CLA in the dietary supplement. Recently, de Veth et al. (2004) combined data from 7 studies in which cows were abomasally infused with trans-10, cis-12 CLA; they showed that the transfer of trans-10, cis-12 CLA to milk fat was linear across abomasal doses. Using this equation, we compared data in the present study, where the transfer of the trans-10, cis-12 CLA from the Ca salts to milk was 3.15 and $2.64 \%$ for CLA-1 and CLA-2, respectively. These values are equivalent to 12 and $14 \%$ of that expected with abomasal infusion of the same doses. Similar calculations comparing the transfer of trans-10, cis-12 CLA from dietary supplements to milk fat showed values of 15 and $22 \%$ of those expected with abomasal infusions for the established lactation study of Perfield et al. (2002) and the early lactation study of Bernal-Santos et al. (2003), respectively. 


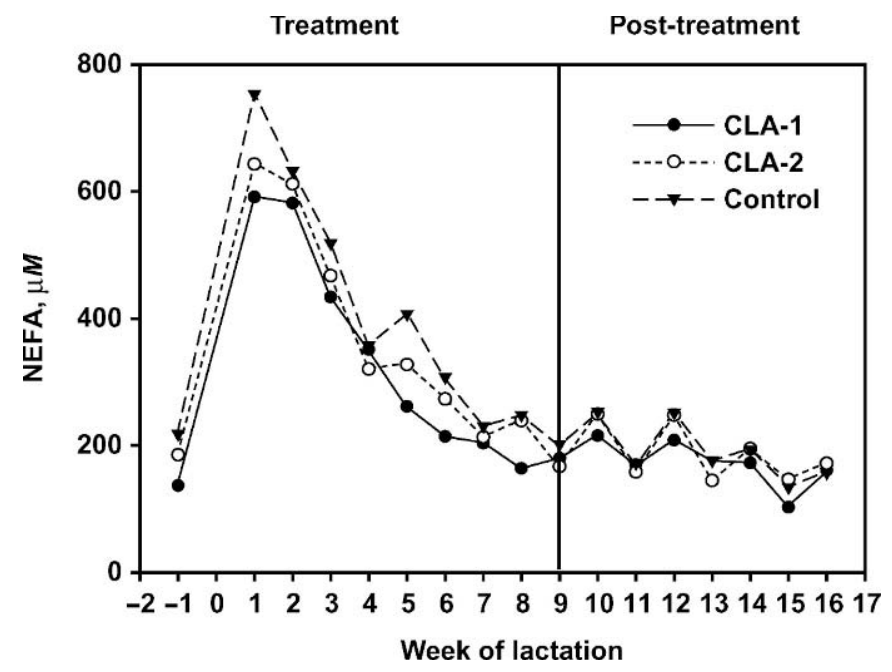

Figure 3. Temporal pattern of NEFA during the treatment $(\mathrm{n}=$ 46) and post-treatment periods $(n=44)$. Cows received a dietary fat supplement for the first 9 wk of lactation consisting of Ca salts of $271 \mathrm{~g} / \mathrm{d}$ of palm fatty acid distillate (control), Ca salts of a mixture of conjugated linoleic acid (CLA) isomers $(147 \mathrm{~g} / \mathrm{d}$ containing $32 \mathrm{~g} / \mathrm{d}$ CLA isomers; $9 \mathrm{~g} / \mathrm{d}$ of CLA trans-10, cis-12) plus $136 \mathrm{~g} / \mathrm{d}$ of palm fatty acid distillate (CLA-1), or Ca salts of a mixture of CLA isomers (295 $\mathrm{g} / \mathrm{d}$ containing $63 \mathrm{~g} / \mathrm{d}$ CLA isomers; $18 \mathrm{~g} / \mathrm{d}$ of CLA trans-10, cis-12; CLA-2). Values are least squares means for each treatment group, and SEM averaged $29 \mu M$; there was no treatment $\times$ week interaction during the treatment period.

The temporal pattern of the CLA-induced reduction in fatty acids was of interest, so we grouped fatty acids according to source (Figure 2). There was a treatment $\times$ week interaction for fatty acids $<\mathrm{C} 16$ and $\mathrm{C} 16(P<$ 0.05). In the cows supplemented with CLA-1, shortand medium-chain fatty acids $(<\mathrm{C} 16)$ accounted for a smaller portion of the reduction during the first few weeks postpartum; however, the proportion increased gradually through the treatment period to where fatty acids $<\mathrm{C} 16$ accounted for $>50 \%$ of the reduction (molar basis) at 6 wk postpartum (Figure 2, top panel). The reduction in fatty acids of cows supplemented with CLA-2 was more equally distributed among sources during the first 2 wk of lactation, but de novo synthesized fatty acids were also more extensively reduced after 3 wk postpartum (Figure 2, bottom panel). During early lactation, mammary uptake of preformed fatty acids is increased, and long-chain fatty acids represent a larger proportion of milk fatty acids (McGuire and Bauman, 2002). Thus, the greater reduction of preformed fatty acids observed with CLA supplements during the first weeks of lactation may be due to the fact that they contributed more extensively to milk fatty acids at the beginning of the lactation.

Milk energy output was significantly lower in the CLA-2 group compared with the control, but the calculated net energy balance over the 9 -wk period and the use of fat reserves as indicated by BW and BCS were not different between treatments (Table 2). Further, DMI did not account for the difference because intake was similar among treatments $(P=0.35)$. Increased energy expenditure and fat oxidation have been reported in growing mice supplemented with CLA (West et al., 1998; Ohnuki et al., 2001), but the doses administered to mice are over 10-fold greater than the dose used in studies with lactating cows (Bauman et al., 2003). If increased energy expenditure occurs in cows, it will result in increased maintenance requirements and increased heat production. However, Shingfield et al. (2004) estimated energy balance of cows fed a control treatment or a rumen-protected CLA at wk 3, 7, 11, and 15 of lactation using excreta collection and respiration calorimetry. They observed increased yields of milk and milk protein, but did not find treatment differences in heat energy $/ \mathrm{BW}^{0.75}$. In the present study, the net energy balance is an estimated value, and there were small numerical differences among treatments for each of the variables used in the calculations. Thus, the aggregation of these small differences may reflect the decrease in the energy expended for milk fat in CLA-treated cows. Further studies to clarify the bioenergetics of energy partitioning in lactating cows supplemented with CLA are needed.

Dietary supplements of CLA have been reported to cause insulin resistance in a few studies. Development of insulin resistance was reported in CLA-treated mice based on response to an insulin challenge, but no differences were observed in response to a glucose tolerance test (Tsuboyama-Kasaoka et al., 2000). Men supplemented with CLA for $12 \mathrm{wk}$ also developed insulin resistance based on results from a euglycemic-hyperinsulinemic clamp, and this effect was attributed specifically to the trans-10, cis-12 isomer of CLA (Riserus et al., 2002a; Riserus et al., 2002b). In the present study, no differences among treatments were observed for plasma glucose or insulin (Table 4). Similarly, long-term studies in lactating cows observed no effect of CLA on plasma concentrations of glucose or insulin (Perfield et al., 2002; Bernal-Santos et al., 2003; Selberg et al., 2004). In addition, short-term studies in dairy cows established that CLA had no effect on plasma concentrations of glucose, insulin, or on the fractional rate of glucose clearance in response to insulin (Baumgard et al., 2000; Baumgard et al., 2002). Thus, at the doses of trans-10, cis-12 CLA that are affective in reducing milk fat secretion, there is no evidence of insulin resistance in the lactating cow.

Liver concentration of triglycerides was not different among treatments (Table 4). This is in accordance with the results reported by Bernal-Santos et al. (2003) and Selberg et al. (2004) and suggests that CLA does not 
Table 5. Reproductive performance of cows receiving the 3 treatments.

\begin{tabular}{|c|c|c|c|c|c|}
\hline \multirow[b]{2}{*}{ Variable } & \multicolumn{3}{|c|}{ Treatment ${ }^{1}$} & \multirow[b]{2}{*}{ SEM } & \multirow[b]{2}{*}{$P$} \\
\hline & Control & CLA-1 & CLA-2 & & \\
\hline \multicolumn{6}{|l|}{ Days to first ovulation } \\
\hline Mean & $32.6^{\mathrm{ab}}$ & $27.3^{\mathrm{a}}$ & $41.4^{\mathrm{b}}$ & \multirow[t]{2}{*}{3.9} & 0.05 \\
\hline Median $^{2}$ & $34.0^{\mathrm{ab}}$ & $21.5^{\mathrm{b}}$ & $41.3^{\mathrm{a}}$ & & 0.05 \\
\hline \multicolumn{6}{|l|}{ Days to pregnancy 3,4} \\
\hline Mean & 160 & 135 & 151 & \multirow[t]{2}{*}{16} & 0.81 \\
\hline Median & 146 & 130 & 124 & & 0.54 \\
\hline $\begin{array}{l}\text { Ovulations before } \\
\text { synchronization }^{5,6}\end{array}$ & 1.6 & 1.7 & 1.5 & \multirow[t]{2}{*}{0.4} & 0.63 \\
\hline \multicolumn{5}{|l|}{ Cows pregnant before } & \\
\hline 126 DIM, \% & 18.7 & 31.3 & 33.3 & & 0.63 \\
\hline \multicolumn{6}{|l|}{ Cows pregnant before } \\
\hline 185 DIM, \% & 43.8 & 81.3 & 53.3 & \multirow{3}{*}{0.4} & 0.07 \\
\hline Services per conception & 2.5 & 2.2 & 2.0 & & 0.57 \\
\hline \multirow{2}{*}{$\begin{array}{l}\text { Proportion of cows with estrogen active } \\
\text { follicles in the first } 21 \text { DIM, }{ }^{7} \% \\
\text { Proportion of cows with ovulation in the } \\
\text { first } 21 \text { DIM, } \%\end{array}$} & 73.3 & 57.1 & 60.0 & & 0.63 \\
\hline & $18.8^{\mathrm{ab}}$ & $46.7^{\mathrm{a}}$ & $7.1^{\mathrm{b}}$ & & 0.03 \\
\hline \multicolumn{6}{|c|}{${ }^{\mathrm{a}, \mathrm{b}}$ Means with a row with different superscripts differ. } \\
\hline \multicolumn{6}{|c|}{$\begin{array}{l}{ }^{1} \text { Cows received a dietary fat supplement consisting of } 271 \mathrm{~g} / \mathrm{d} \text { of Ca salts of palm fatty acid distillate } \\
\text { (control), Ca salts of a mixture of conjugated linoleic acid (CLA) isomers (147g/d containing } 32 \mathrm{~g} / \mathrm{d} \text { of CLA } \\
\text { isomers; } 9 \mathrm{~g} / \mathrm{d} \text { of CLA trans-10, cis-12) plus } 136 \mathrm{~g} / \mathrm{d} \text { of palm fatty acid distillate (CLA-1), or Ca salts of a } \\
\text { mixture of CLA isomers }(295 \mathrm{~g} / \mathrm{d} \text { containing } 63 \mathrm{~g} / \mathrm{d} \text { of CLA isomers; } 18 \mathrm{~g} / \mathrm{d} \text { of CLA trans-10, cis-12; CLA-2). }\end{array}$} \\
\hline \multicolumn{6}{|c|}{$\begin{array}{l}{ }^{2} \text { Cows were censored when ovulation did not occur before synchronization (one from each treatment). } \\
{ }^{3} \text { Pregnancies recorded before } 185 \mathrm{~d} \text { postpartum }(\mathrm{n}=44) \text {. }\end{array}$} \\
\hline \multicolumn{6}{|c|}{$\begin{array}{l}{ }^{4} \text { Cows were censored if not pregnant before } 185 \mathrm{~d} \text { ( } 3 \text { from CLA-1, } 5 \text { from CLA-2, and } 8 \text { from the control } \\
\text { group). }\end{array}$} \\
\hline \multicolumn{6}{|c|}{${ }^{5}$ Synchronization occurred at $67 \mathrm{~d}$ postpartum. } \\
\hline \multicolumn{6}{|c|}{$\begin{array}{l}{ }^{6} \text { Ovulation determined when plasma progesterone levels were }>0.5 \mathrm{ng} / \mathrm{mL} \text { for at least } 5 \text { consecutive samples } \\
\text { and exceeded } 2 \mathrm{ng} / \mathrm{mL} \text { for at least } 2 \text { successive samples. }\end{array}$} \\
\hline
\end{tabular}

have an effect on hepatic fat accumulation in early lactation. Plasma concentrations of NEFA did not differ between treatments over the 9-wk treatment period (Table 4). However, the group supplemented with CLA$1 \mathrm{had}$ a lower value during the first week postpartum $(P<0.05)$ and tended to have lower plasma NEFA concentrations during the first $9 \mathrm{wk}$ (Figure 3 ). Other studies in early and established lactation have not observed differences in NEFA caused by treatment with CLA (Perfield et al., 2002; Bernal-Santos et al., 2003; Moore et al., 2004). In contrast, Baumgard et al. (2002) observed a trend to decrease plasma NEFA concentrations after an epinephrine challenge in a short-term study (5 d), where cows were abomasally infused with $10 \mathrm{~g} /$ d of trans-10, cis-12 CLA.

Reproductive performance data are limited by number of cows; nevertheless, the numerical responses to CLA in the present study (Table 5) are comparable with results reported in earlier studies that had similar numbers of animals (Medeiros et al., 2000; Bernal-Santos et al., 2003). Both of these earlier studies observed a trend for fewer days to first ovulation and a reduction in the number of days open for cows supplemented with CLA. In the present study, the median days to first ovulation was numerically lower for cows supplemented with CLA-1. There was a trend $(P=0.07)$ for the proportion of cows pregnant before $185 \mathrm{~d}$ to differ among treatments, with the highest value observed for the CLA-1 group (Table 5). The percentage of cows pregnant before 126 DIM of the 2 CLA groups was similar (31.1 and $33.3 \%$ ) and numerically greater than the control group $(18.7 \%)$.

The role of fat supplements in reproduction has been extensively investigated. The positive influence of fat may relate to effects on energy status or may be related to the specific fatty acid profile of the supplement. Fatty acids may improve reproduction through increased ovarian steroidogenesis, manipulation of insulin to stimulate ovarian follicle development, and/or inhibition of the uterine production and release of $\mathrm{PGF}_{2 \alpha}$ (Mattos et al., 2000). The inhibition of $\mathrm{PGF}_{2 \alpha}$ can decrease embryonic loss by avoiding luteolysis when maternal recognition of pregnancy does not occur (Abayasekara and Wathes, 1999). Conjugated linoleic acid has been reported to have an effect on prostaglandin synthesis in several different species and cell systems (Belury, 2002). Of special interest is the inhibition of $\mathrm{PGF}_{2 \alpha}$ observed in uterine tissue of pregnant rats supple- 
Table 6. Least squares means for performance parameters and milk composition during the post-treatment period. ${ }^{1}$

\begin{tabular}{|c|c|c|c|c|c|c|}
\hline \multirow[b]{2}{*}{ Variable } & \multicolumn{3}{|c|}{ Treatment } & \multirow[b]{2}{*}{ SEM } & \multirow[b]{2}{*}{$P$} & \multirow{2}{*}{$\begin{array}{l}\text { Treatment } \\
\times \text { week } \\
(P)\end{array}$} \\
\hline & Control & CLA-1 & CLA-2 & & & \\
\hline \multicolumn{7}{|c|}{ Performance parameter } \\
\hline Milk yield, kg/d & 46.7 & 45.2 & 48.4 & 1.7 & 0.42 & 0.003 \\
\hline $\mathrm{BW},{ }^{2} \mathrm{~kg}$ & 628 & 633 & 600 & 13.8 & 0.19 & 0.30 \\
\hline $\mathrm{BCS}^{3}$ & 2.6 & 2.7 & 2.5 & 0.1 & 0.21 & 0.58 \\
\hline \multicolumn{7}{|l|}{ Milk composition } \\
\hline \multicolumn{7}{|l|}{ Milk fat } \\
\hline$\%$ & 3.60 & 3.48 & 3.30 & 0.10 & 0.12 & 0.26 \\
\hline Yield, kg/d & 1.69 & 1.55 & 1.60 & 0.05 & 0.15 & 0.61 \\
\hline \multicolumn{7}{|l|}{ Milk protein } \\
\hline$\%$ & 2.79 & 2.71 & 2.65 & 0.05 & 0.08 & 0.73 \\
\hline Yield, kg/d & 1.30 & 1.22 & 1.29 & 0.04 & 0.29 & 0.16 \\
\hline \multicolumn{7}{|l|}{ Milk lactose } \\
\hline$\%$ & 4.79 & 4.80 & 4.76 & 0.05 & 0.83 & 0.86 \\
\hline Yield, kg/d & 2.24 & 2.17 & 2.32 & 0.07 & 0.33 & 0.05 \\
\hline
\end{tabular}

${ }^{1}$ Values represent data obtained from 10 to $18 \mathrm{wk}$ postpartum.

${ }^{2}$ Cows were weighed after milking on $1 \mathrm{~d} / \mathrm{wk}$.

${ }^{3}$ Cows were scored weekly using a 5 -point scale by the same individual.

mented with CLA (Harris et al., 2001) and the decreased production of $\mathrm{PGF}_{2 \alpha}$ in endometrial cells incubated with CLA (Cheng et al., 2003). Large-scale field studies will be required to establish more clearly the effect of CLA in reproduction.

Production-related variables for the post-treatment period are presented in Table 6. No differences were observed in milk production or milk components because of treatment. There was a significant treatment $\times$ week interaction for milk and milk lactose yields, and this was due to slightly greater yields in the CLA-2 group for wk 1 to 3 post-treatment. Milk fat depression was reversible, and milk fat content of the CLA groups returned to levels similar to the control group when the CLA supplement was terminated (Figure 1). This is in accordance with the temporal pattern observed in short-term studies with abomasal infusions of CLA (Chouinard et al., 1999a,b; Baumgard et al., 2000). Thus, the present study shows that CLA may be supplemented for the first $9 \mathrm{wk}$ postpartum without any posttreatment effects.

\section{CONCLUSIONS}

Dietary supplements of CLA during the transition period and early lactation induced a progressive, doserelated reduction in milk fat. Effects were specific for milk fat, and there were no differences in milk yield or in the yield of milk lactose or protein. At the higher dose, the CLA-induced milk fat depression decreased milk energy output, but this was not reflected in a statistically significant improvement in net energy balance or reduction in the use of body fat reserves as evaluated by changes in BW or BCS. A complete assessment of reproductive performance will require greater cow numbers, but apparent improvements were observed for the group supplemented with CLA-1, and a trend toward increased number of cows pregnant was observed for both CLA treatment groups.

Further studies are needed to clarify the partitioning of energy in CLA-supplemented cows. Of particular interest is the use of the energy spared by the reduction in milk fat with CLA supplementation in early lactation and to elucidate the basis for the variability in the response in milk yield seen in other studies. Additionally, large-scale studies are necessary to establish definitively the effects of dietary CLA supplements on reproduction of dairy cows.

\section{ACKNOWLEDGMENTS}

The authors express their gratitude to Daniel Luchini (Bioproducts Inc.) for providing the fatty acid supplements and to Angelika Maria Pfeiffer (BASF AG) for assisting in the development of this research. The assistance of Debbie Dwyer, Michael de Veth, Mary Schwartz, Tom Muscato, Gladys Birdsall, Ray Axtell, and Jim Perfield in the development and conduct of this trial is kindly appreciated.

\section{REFERENCES}

Abayasekara, D. R., and D. C. Wathes. 1999. Effects of altering dietary fatty acid composition on prostaglandin synthesis and fertility. Prostaglandins Leukot. Essent. Fatty Acids 61:275-287.

Allen, M. S. 2000. Effects of diet on short-term regulation of feed intake by lactating dairy cattle. J. Dairy Sci. 83:1598-1624. 
Bauman, D. E. 2000. Regulation of nutrient partitioning during lactation: Homeostasis and homeorhesis revisited. Pages 311-328 in Ruminant Physiology: Digestion, Metabolism, Growth and Reproduction. P. J. Cronje, ed. CAB International, New York, NY.

Bauman, D. E., B. A. Corl, and D. G. Peterson. 2003. The biology of conjugated linoleic acids in ruminants. Pages 146-173 in Advances in Conjugated Linoleic Acid Research. Vol. 2. J. L. Sebedio, W. W. Christie, and R. O. Adlof, ed. AOCS Press, Champaign, IL.

Bauman, D. E., and J. M. Griinari. 2003. Nutritional regulation of milk fat synthesis. Annu. Rev. Nutr. 23:203-227.

Baumgard, L. H., B. A. Corl, D. A. Dwyer, and D. E. Bauman. 2002. Effects of conjugated linoleic acids (CLA) on tissue response to homeostatic signals and plasma variables associated with lipid metabolism in lactating dairy cows. J. Dairy Sci. 80:1285-1293.

Baumgard, L. H., B. A. Corl, D. A. Dwyer, A. Sæbø, and D. E. Bauman. 2000. Identification of the conjugated linoleic acid isomer that inhibits milk fat synthesis. Am. J. Physiol. 278:R179-R184.

Baumgard, L. H., J. K. Sangster, and D. E. Bauman. 2001. Milk fat synthesis in dairy cows is progressively reduced by increasing supplemental amounts of trans-10, cis-12 conjugated linoleic acid (CLA). J. Nutr. 131:1764-1769.

Beam, S. W., and W. R. Butler. 1997. Energy balance and ovarian follicle development prior to the first ovulation postpartum in dairy cows receiving three levels of dietary fat. Biol. Reprod. $56: 133-142$

Bell, A. W. 1995. Regulation of organic nutrient metabolism during transition from late pregnancy to early lactation. J. Anim. Sci. 73:2804-2818.

Belury, M. A. 2002. Inhibition of carcinogenesis by conjugated linoleic acid: Potential mechanisms of action. J. Nutr. 132:2995-2998.

Bernal-Santos, G., J. W. Perfield, II, D. M. Barbano, D. E. Bauman, and T. R. Overton. 2003. Production responses of dairy cows to dietary supplementation with conjugated linoleic acid (CLA) during the transition period and early lactation. J. Dairy Sci. 86:3218-3228.

Butler, W. R., R. W. Everett, and C. E. Coppock. 1981. The relationships between energy balance, milk production and ovulation in postpartum Holstein cows. J. Anim. Sci. 53:742-748.

Cheng, Z., M. Elmes, D. R. E. Abayasekara, and D. C. Wathes. 2003. Effects of conjugated linoleic acid on prostaglandins produced by cells isolated from maternal intercotyledonary endometrium, fetal allantochorion and amnion in late pregnant ewes. Biochim. Biophys. Acta 1633:170-178.

Chouinard, P. Y., L. Corneau, D. M. Barbano, L. E. Metzger, and D. E. Bauman. 1999a. Conjugated linoleic acids alter milk fatty acid composition and inhibit milk fat secretion in dairy cows. J. Nutr. 129:1579-1584.

Chouinard, P. Y., L. Corneau, A. Sæbø, and D. E. Bauman. 1999b. Milk yield and composition during abomasal infusion of conjugated linoleic acids in dairy cows. J. Dairy Sci. 82:2737-2745.

Coppock, C. E., C. H. Noller, S. A. Wolfe, C. J. Callahan, and J. S. Baker. 1972. Effects of forage-concentrate ratio in complete feeds fed ad libitum on feed intake prepartum and the occurrence of abomasal displacement in dairy cows. J. Dairy Sci. 55:783-789.

de Veth, M. J., M. Griinari, A. M. Pfeiffer, and D. E. Bauman. 2004. Effect of CLA on milk fat synthesis in dairy cows: Comparison of inhibition by methyl esters and free fatty acids, and relationships among studies. Lipids 39:365-372.

Drackley, J. K. 1999. Biology of dairy cows during the transition period: The final frontier? J. Dairy Sci. 82:2259-2273.

Elrod, C. C., and W. R. Butler. 1993. Reduction of fertility and alteration of uterine $\mathrm{pH}$ in heifers fed excess ruminally degradable protein. J. Anim. Sci. 71:694-701.

Fletcher, M. J. 1968. A colorimetric method for estimating serum triglycerides. Clin. Chim. Acta 22:393-397.

Folch, J., M. Lees, and G. H. S. Stanley. 1957. A simple method for the isolation and purification of total lipids from animal tissues. J. Biol. Chem. 226:497-509.

Foster, L. B., and R. T. Dunn. 1973. Stable reagents for determination of serum triglycerides by a colorimetric Hantzsch condensation method. Clin. Chem. 19:338-340.
Fox, D. G., L. O. Tedeschi, T. P. Tylutki, J. B. Russell, M. E. Van Amburgh, L. E. Chase, A. N. Pell, and T. R. Overton. 2004. The Cornell Net Carbohydrate and Protein System model for evaluating herd nutrition and nutrient excretion. Anim. Feed Sci. Technol. 112:29-78.

Giesy, J. G., M. A. McGuire, B. Shafii, and T. W. Hanson. 1999. Effects of calcium salts of conjugated linoleic acid (CLA) on milk production and energy balance of early lactation Holsteins. J. Dairy Sci. 82(Suppl. 1):83. (Abstr.)

Goff, J. P., and R. L. Horst. 1997. Physiological changes at parturition and their relationship to metabolic disorders. J. Dairy Sci. 80:1260-1268.

Gröhn, Y. T., S. W. Eicker, and J. A. Hertl. 1995. The association between previous 305-day milk yield and disease in New York state dairy cows. J. Dairy Sci. 78:1693-1702.

Grummer, R. R. 1995. Impact of changes in organic nutrient metabolism on feeding the transition dairy cow. J. Anim. Sci. 73:2820-2833.

Harris, M. A., R. A. Hansen, J. L. Koslo, J. B. Thomas, B. A. Watkins, and K. G. D. Allen. 2001. Effects of conjugated linoleic acids and docosahexaenoic acid on rat liver and reproductive tissue fatty acids, prostaglandins and matrix metalloproteinase production. Prostaglandins Leukot. Essent. Fatty Acids 65:23-29.

Hayirli, A., R. R. Grummer, E. V. Nordheim, and P. M. Crump. 2002. Animal and dietary factors affecting feed intake during the prefresh transition period in Holsteins. J. Dairy Sci. 85:34303443.

Mashek, D. G., and R. R. Grummer. 2003. Feeding pre-fresh transition cows: Should we maximize feed intake or minimize feed intake depression? J. Dairy Sci. 86(Suppl. 1):11. (Abstr.)

Mattos, R., C. R. Staples, and W. W. Thatcher. 2000. Effects of dietary fatty acids on reproduction in ruminants. Rev. Reprod. 5:38-45.

McGuire, M. A., and D. E. Bauman. 2002. Milk biosynthesis and secretion. Pages 1828-1834 in Encyclopedia of Dairy Sciences. H. Roginski, J. W. Fuquay, and P. F. Fox, ed. Elsevier Science Ltd., London, UK.

McGuire, M. A., J. M. Griinari, D. A. Dwyer, and D. E. Bauman. 1995. Role of insulin in the regulation of mammary synthesis of fat and protein. J. Dairy Sci. 78:816-824.

Medeiros, S. R., D. E. Oliveira, L. J. M. Aroeira, M. A. McGuire, D. E. Bauman, and D. P. D. Lanna. 2000. The effect of long term supplementation of conjugated linoleic acid (CLA) to dairy cows grazing tropical pasture. J. Dairy Sci. 83(Suppl. 1):169. (Abstr.)

Moore, C. E., H. C. Hafliger, III, O. B. Mendivil, S. R. Sanders, D. E. Bauman, and L. H. Baumgard. 2004. Increasing amounts of conjugated linoleic acid (CLA) progressively reduce milk fat synthesis immediately postpartum. J. Dairy Sci. 87:1886-1895.

National Research Council. 2001. Pages 13-33 in Nutrient Requirements of Dairy Cattle. 7th rev. ed. Natl. Acad. Sci., Washington, DC.

Ohnuki, K., S. Haramizu, K. Oki, K. Ishihara, and T. Fushiki. 2001. A single oral administration of conjugated linoleic acid enhanced energy metabolism in mice. Lipids 36:583-587.

Oldham, J. D. 1984. Protein-energy interrelationships in dairy cows. J. Dairy Sci. 67:1090-1114.

Perfield, J. W., G. Bernal-Santos, T. R. Overton, and D. E. Bauman. 2002. Effects of dietary supplementation of rumen-protected conjugated linoleic acid in dairy cows during established lactation. J. Dairy Sci. 85:2609-2617.

Peterson, D. G., L. H. Baumgard, and D. E. Bauman. 2002. Short communication: Milk fat response to low doses of trans-10, cis12 conjugated linoleic acid (CLA). J. Dairy Sci. 85:1764-1766.

Riserus, U., P. Arner, K. Brismar, and B. Vessby. 2002a. Treatment with dietary trans10cis 12 conjugated linoleic acid causes isomerspecific insulin resistance in obese men with the metabolic syndrome. Diabetes Care 25:1516-1521.

Riserus, U., S. Basu, S. Jovinge, G. N. Fredrikson, J. Arnlov, and B. Vessby. 2002b. Supplementation with conjugated linoleic acid causes isomer-dependent oxidative stress and elevated c-reactive protein: A potential link to fatty acid-induced insulin resistance. Circulation 106:1925-1929.

SAS User's Guide. Statistics, Version 8. 2001. SAS Inst., Inc., Cary, NC. 
Sechen, S. J., F. R. Dunshea, and D. E. Bauman. 1990. Somatotropin in lactating cows-Effect on response to epinephrine and insulin. Am. J. Physiol. 258:E582-E588.

Selberg, K. T., A. C. Lowe, C. R. Staples, N. D. Luchini, and L. Badinga. 2004. Production and metabolic responses of periparturient Holstein cows to dietary conjugated linoleic acid and transoctadecenoic acids. J. Dairy Sci. 87:158-168.

Shingfield, K. J., D. E. Beever, C. K. Reynolds, S. K. Gulati, D. J. Humphries, B. Lupoli, G. Hervás, and J. M. Griinari. 2004. Effect of rumen protected conjugated linoleic acid on energy metabolism of dairy cows during early to mid-lactation. J. Dairy Sci. 87(Suppl. 1):307. (Abstr.)

Tsuboyama-Kasaoka, N., M. Takahashi, K. Tanemura, H. J. Kim, T. Tange, H. Okuyama, M. Kasai, S. Ikemoto, and O. Ezaki. 2000.
Conjugated linoleic acid supplementation reduces adipose tissue by apoptosis and develops lipodystrophy in mice. Diabetes 49:1534-1542.

Veenhuizen, J. J., J. K. Drackley, M. J. Richard, T. P. Sanderson, L. D. Miller, and J. W. Young. 1991. Metabolic changes in blood and liver during development and early treatment of experimental fatty liver and ketosis in cows. J. Dairy Sci. 74:4238-4253.

West, D. B., J. P. Delany, P. M. Camet, F. Blohm, A. A. Truett, and J. Scimeca. 1998. Effects of conjugated linoleic acid on body fat and energy metabolism in the mouse. Am. J. Physiol. 44:R667-R672.

Wildman, E. E., G. M. Jones, P. E. Wagner, R. L. Boman, H. F. Trout, and T. N. Lesch. 1982. A dairy cow body condition scoring system and its relationship to selected production variables in high producing Holstein dairy cattle. J. Dairy Sci. 65:495-501. 